\title{
Royong Sebagai Bentuk Penanaman Nilai-Nilai Pendidikan
}

\author{
Arifin Manggau $^{\text {a, }{ }^{*} \text {, Sayidiman }}{ }^{\mathrm{b}, 2}$ \\ ${ }^{\mathrm{a}, \mathrm{b}}$ Universitas Negeri Makassar, Indonesia \\ 1 arifin.manggau@unm.ac.id*; sayidiman@unm.ac.id \\ *korespondensi penulis
}

\section{Informasi artikel}

Received :

July 02, 2019.

Revised :

July 31, 2019.

Publish :

August 31, 2019.

Kata kunci:

Royong

Nilai Pendidikan

Keywords:

Royong

Education Value

\begin{abstract}
ABSTRAK
Tujuan dari penelitian ini adalah untuk mendeskripsikan penanaman nilai-nilai pendidikan melalui nyaian royong di Sulawesi Selatan. Penelitian ini menggunakan pendekatan kualitatif dengan jenis penelitian interdisiplin yaitu dengan menggunakan lebih dari satu disiplin ilmu menjadi satu. Teknik pengumpulan data yang dipergunakan adalah observasi dan indepth interview serta studi dokumen. Hasil penelitian menunjukkan bahwa royong memiliki beberapa fungsi yaitu sebagai pengantar tidur, penanaman nilai pendidikan dan mendatangkan rezeki. Royong digunakan dalam beberapa adat atau kebiasaan masyarakat Makassar seperti : perkawinan, aqiqah, penolak bala, serta sebagai media pola asuh penanaman nilai-nilai pendidikan pada anak (penanaman budi pekerti etika yang baik). Lagu pengantar tidur (Royong), merupakan pola asuh seorang ibu/ nenek kepada anak/ cucunya karena isi/ lirik lagunya mengandung ajaran moral, nasehat atau doa-doa untuk anaknya yang dijadikan salah satu cara membuat anak selalu ingat akan petuah/ ajaran yang diucapkan ibu/ neneknya.
\end{abstract}

\begin{abstract}
Royong As A Form Of Planting Educational Values. The purpose of this study is to describe the cultivation of educational values through Royong song in South Sulawesi. This study uses a qualitative approach to the type of interdisciplinary research by using more than one discipline into one. Data collection techniques used were observation and in-depth interviews and document studies. The results showed that Royong has several functions, namely as a lullaby, planting educational values and bringing fortune. Royong is used in a number of cultures or habits of the Makassar community such as marriage, aqiqah, rejection of reinforcements, as well as media for raising parental values of education in children (the cultivation of good manners). Lullaby (Royong), is parenting style for a mother/grandmother to her child/grandchildren because the contents/lyrics of the song contain moral teachings, advice or prayers for their children which are used as a way to make children always remember the advice/teachings spoken by the mother/grandmother.
\end{abstract}

Copyright $\left({ }_{0} 2019\right.$ (Arifin Manggau, Sayidiman). All Right Reserved

How to Cite: Manggau, A., \& Sayidiman, S. (2019). Royong Sebagai Bentuk Penanaman Nilai-Nilai Pendidikan. Jurnal Inspirasi Pendidikan, 9(2), 123-133.

This work is licensed under a Creative Commons Attribution-ShareAlike 4.0 International License. Allows readers to read, download, copy, distribute, print, search, or link to the full texts of its articles and allow readers to use them for any other lawful purpose. The journal hold the copyright.

\section{Pendahuluan}

Sulawesi Selatan merupakan salah satu provinsi di Indonesia dengan tingkat keragaman budaya yang tinggi. Di Gowa, ada sebuah kebiasaan menarik yang sering dilakukan oleh ibu-ibu sesaat sebelum bayinya tertidur. Sang ibu melantunkan sebuah nyanyian pengantar tidur, yang dinyanyikan tanpa iringan alat musik, tetapi menggunakan syair-syair tertentu dalam bahasa Makassar. Seiring dengan melantunkan syair-syair, sang ibu biasanya mengayun-ayun bayi secara perlahan hingga matanya terpejam. Nyanyian tersebut dikalangan masyarakat Makassar disebut: royong. 
Nyanyian ini dilantunkan oleh orang-orang terdahulu yaitu ibu kepada bayinya atau nenek kepada cucunya. Saat ini, royong sudah hampir tidak pernah lagi terdengar pada masyarakat Makassar. Disebabkan karena nyanyian royong tidak diajarkan kepada keturunan atau sanak famili. Orang tua terdahulu melantunkan royong hanya sebatas sampai anak atau cucunya tertidur, setelah tertidur liriknya tidak dilanjutkan lagi. Sehingga saat ini, lirik lagu royong yang dikenal dari hasil dokumentasi sangat pendek. Apalagi sekarang orang-orang tua yang berumur 70/80 tahun yang lalu, yang diperkirakan memiliki pengetahuan tentang royong sudah banyak yang meninggal dunia.

Ketika membaca atau mendengar secara sekilas naskah royong yang ada, maka dapat dikatakan bahwa kata-kata yang terdapat dalam naskah royong tersebut sudah banyak yang tidak diketahui artinya, terutama bagi generasi muda sekarang ini karena kata-kata tersebut sudah jarang didengar ataupun dipergunakan dalam bahasa percakapan sehari-hari dalam masyarakat Makassar. Apabila naskah itu dibaca atau disimak secara mendalam, maka royong tersebut dilantunkan dengan maksud agar orang yang dilantunkan itu mendapat keselamatan, kesenangan, kebahagiaan, ketentraman dan kesejahtraan dalam kehidupannya.

Royong adalah sejenis nyanyian untuk anak-anak kecil (bayi) yang masih berumur 40 hari. Melantunkannya tanpa diiringi musik, sambil bayi diayun-ayunkan perlahan sampai tidur terlelap. AlAfandi (2015) mengungkapkan bahwa nilai yang terkandung dalam buaian lagu (mompaova) meliputi (1) nilai-nilai moral, (2) philosophicalvalue, (3) nilai religius, (4) nilai-nilai sosial, dan (5) nilai estetika. Sisi lain dari fungsinya sebagai pengantar tidur, royong juga dilantukan pada pesta penyunatan (pasunakkang), perkawinan (pakbuntingang) atau pun pada acara aqiqah (pattompolang/-anngalle areng). Khusus pada pesta adat, penyajian royong biasanya diiringi dengan alat musik tradisional, seperti anak baccing, kancing, curiga, gong, ganrang, puik-puik, dengkang, dll. Royong pada acara adat dilantunkan oleh orang yang sudah lanjut usia. Selain daripada itu,bagi masyarakat suku Makassar yang mempercayainya bahwa lantunan royong dapat menyembuhkan penyakit, menolak bala dan sebagainya. Hal itu dikarenakan syair royong menyerupai sebuah doa dan harapan kepada Yang Maha Kuasa(Salim, 2011). Oleh karena itu, sejalan dengan pemaparan dan penjelasan di atas, maka dalam tulisan ini akan mengungkapkan tentang bentuk penyajian dan fungsi royong sebagai pengantar tidur anak bagi suku Makassar di Sulawesi Selatan dan sebagai bentuk penanaman nilai pendidikan melalui seni budaya tradisional yang ada pada suku Makassar.

\section{Metode}

Penelitian ini menggunakan model penelitian kualitatif dengan pendekatan interdisiplin yaitu dengan menggunakan lebih dari satu disiplin ilmu menjadi satu (Frankel \& E., 2008). Penelitian ini yakni memahami fenomena tentang apa yang dialami oleh subjek penelitian secara holistik, dan dengan cara deskripsi dalam bentuk kata-kata dan bahasa, pada suatu konteks khusus yang alamiah dan dengan memanfaatkan berbagai metode ilmiah (Moleong, 2007). Teknik pengumpulan data yang dipergunakan adalah observasi dan indepth interview serta studi dokumen. Teknik Pemeriksaan Keabsahan Data melalui triangulasi dengan melakukan kroscek validitas data yang diperoleh dari lapangan kepada beberapa informan kunci (Sumaryanto, 2007). Langkah-langkah Analisis data dalam penelitian ini sepert pada gambar 1

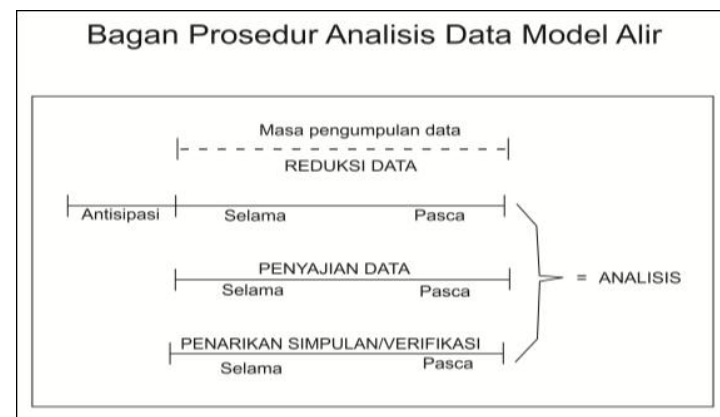

Gambar 1 Bagan Prosedur Analisis Data Model Alir (Sugiyono, 2013) 
Jurnal Inspirasi Pendidikan, VOL.9, NO.2, Edisi Agustus 2019

Royong Sebagai Bentuk Penanaman Nilai-Nilai Pendidikan

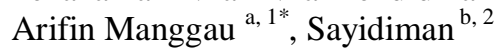

Hal: $123-133$

\section{Hasil dan pembahasan}

\subsection{Royong Pattinro Ana'}

Royong, sejenis nyanyian untuk anak-anak kecil (bayi) selama empat puluh hari sesudah kelahirannya. Royong itu disebut juga Pajjapa daeng sesuai dengan permulaan lagu itu; juga biasa disebut turineung (turienau) ataupun tironaung (tironau) yang berarti melihat dari tempat yang tinggi keumat manusia. Berdasarkan isinya maka namanya pun bermacam-macam pula. Ada yang diberi nama cuwi, kurru-kurru jangang dan turinaung. Disamping yang dilafal oleh orang tua banyak pula yang ditulis pada daun lontar dengan memakai huruf Makassar kuno. Setelah islam berpengaruh dalam masyarakat Makassar banyak kata yang dianggap lebih mulia dan dapat menambah kesaktiannya, menggantikan kata-kata Makassar asli. Ini terdapat dalam jenis royong yang bernama cuwi nilakborak. Kadang-kadang juga royong itu hanya dilagukan oleh seorang perempuan pengasuh. Sambil menimang-nimang atau membuai-buai seorang bayi, ia melakukan royong itu dan membayangkan seakan-akan bayi itu telah dewasa. Inilah yang disebut turinaung.

\subsection{Syair Royong Pattinro Ana'}

Sebelumnya telah dipaparkan bahwa Royong Pattinro Ana' berbeda-beda berdasarkan isinya. Royong sebagai salah satu sastra lisan, cara penyampaiannya hanya dihafal oleh orang-orang tua jaman dahulu, sehingga apabila tidak diantisipasi sedini mungkin maka naskah ini dikhawatirkan akan punah. Meskipun demikian, naskah ini sudah ada yang berhasil didokumentasikan, seperti Royong cuwi nilakborak.

* Teks Royong Cuwi Nilakborak

\section{Lontara:}

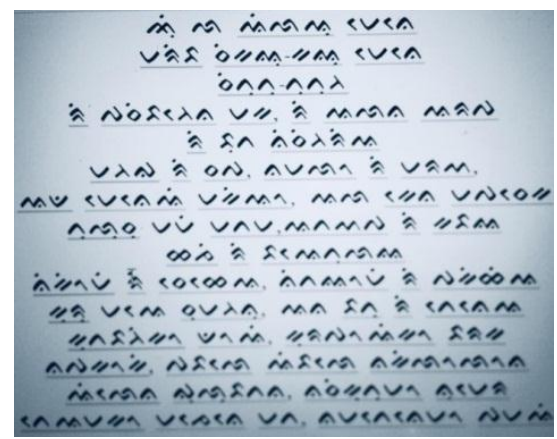

Gambar 2. Teks Lontara Royong Cuwi Nilakborak

\section{Latin:}

Cui la ilau'mene..

manri'ba' sikayu-kayu mene situntung-tuntungang

ri passimbangenna Makka, ri alla'na Arapa

ri butta nisingarria...

manngagaang ri Sapa, nammalo ri Marawa, ada menei makkio', ala kenna mappasengka tulusu'mami mantama, attawapa' ri ka'bayya ha'ji ri baetullayya...

nikio'mi ri sehea, nitayomi ri pakkihia

kurru mae sumanga'nu, anak battu rite'nea

kutimbangiko doing, kurappoiko barakka'

napappokoki, pa'balle iballe nakkilolonna...

ilena gulu'battanna, nasikuntumo numera

teamako ma'je'ne' mata, namate'nemo pa'mai'...

\section{Terjemahan:}

Datanglah burung cuwi..

Terbang sendirian

Melayang tak hinggap-hinggap

Diperbatasan Mekkah, diantara Arafah

Tanah yang diterangi 
Lalu di Syafa, melewati Marwa

Ada dia yang memanggil, mana yang menyinggahkan

Maka teruslah masuk, bertawaf di Ka'bah

Haji di Baitullah..

Dipanggilah oleh Syekh, Dijemput oleh Fakih,

Teriakan semangatmu, anak yang datang dari kebahagiaan,

Kuhadiahi engkau doa, kukajikan untukmu berkat

Yang jadi sumber obat-obat penghias remaja,

Penawar isi perutnya, maka semuanya menginginkan

Tak mau lagi berair mata dan bahagialah

Teks Royong Turinaung

1. Lontara:

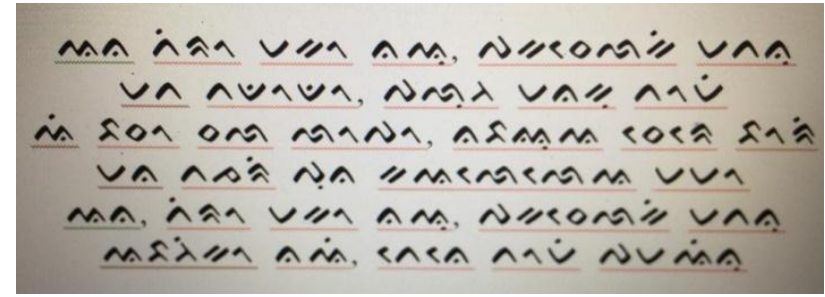

Gambar 3. Teks Lontara Royong Turinaung 1

\section{Latin:}

Ana' tinro mako naung, pakaselaki matannu..

Mata ta'do'do', pa'lungang manakku tommi..

I Baso sallang lompo, na'bayuang se're bori...

Manna tanjari, punna kaleleang mamo...

Ana'... tinro mako naung, pakaselaki matannu..

Ambangungko nai', te'ne tommi pa'mai'nu...

\section{Terjemahan:}

Tidurlah anakku sayang, lelapkanlah matamu

Mata mengantuk, bantalpun telah merindukanmu

Bila nanti engkau dewasa, menjadi kekasih seluruh alam

Walau tak jadi, asalkan sudah terbagi

Tidurlah anakku sayang, lelapkanlah matamu

Bila nanti engkau bangun, bahagia sudah perasaanmu.

\section{Lontara:}

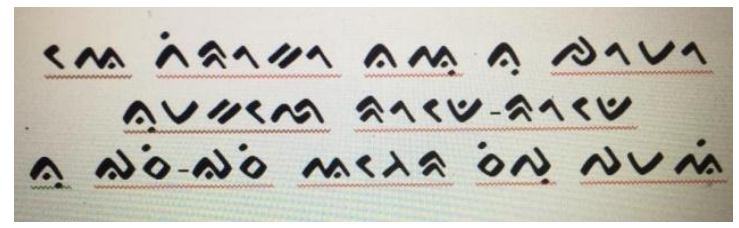

Gambar 4. Teks Lontara Royong Turinaung 2

Latin:

E tinroko naung nu co'mo

Numakale rodeng-rodeng

$\mathrm{Nu}$ gassing-gassing anngerang simpung pa'mai

Terjemahan:

Tidurlah kamu supaya gemuk

Sehingga bagus badanmu

Sehingga kuat membawa duka hati 


\section{Lontara:}

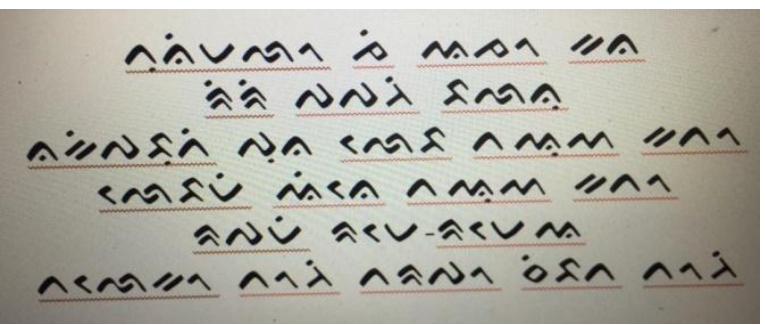

Gambar 5. Teks Lontara Royong Turinaung 3

\section{Latin:}

Tunimalo ji anjo kana

Rinring papangi ballaknu

Nakipakbunting punna lekbak tauwa katto

Lekbakmi inne tauwa katoo

Rampami rame-ramea

Taleko tongi tarappo sibatta tongi

Terjemahan:

Hanya orang lewat yang bilang

Rumahmu berdinding papan

Merayakan pengantin jikalau orang sudah panen padi

Sekarang sudah selesai orang panen

Selesai sudah keramaian

Bukan daun juga bukan setengah buah

\section{Lontara:}

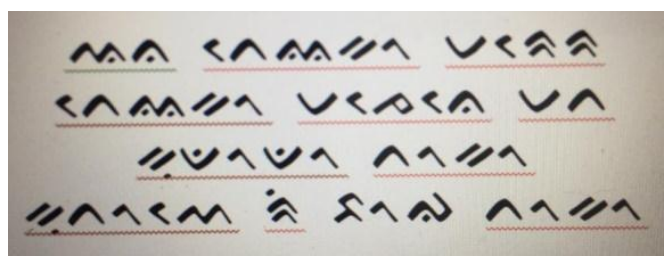

Gambar 6. Teks Lontara Royong Turinaung 4

\section{Latin:}

Ana' teyako marera

Teyako ma'jene mata

Kudondo tongko

Kutoweng ri bongga tongko

Terjemahan:

Anak janganlah kau bersedih

Janganlah kau menangis

$\mathrm{Ku}$ timang juga kau

$\mathrm{Ku}$ ayunkan juga kau di paha

\section{Lontara:}

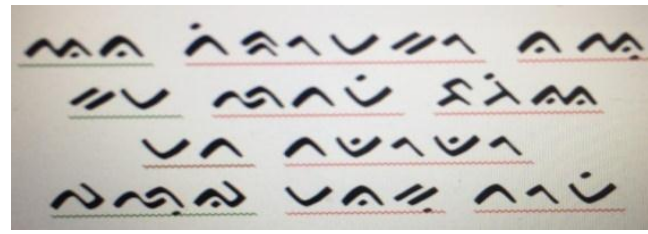

Gambar 7. Teks Lontara Royong Turinaung 5

Latin:

Ana tinromako naung

Kama lantammi bangngiya

Mata ta'dodo 
Palungang manakku tommi

Terjemahan:

Anak tidurlah kamu

Karena sudah tengah malam

Mata mengantuk

Bantalpun sudah merindukanmu

\section{Lontara:}

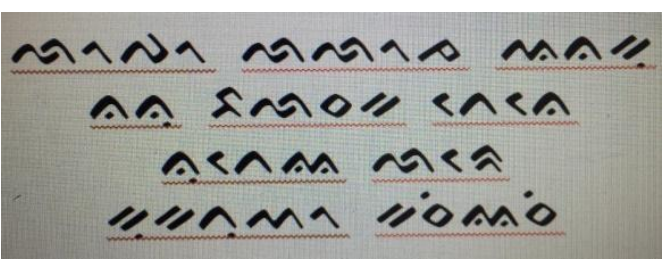

Gambar 8. Teks Lontara Royong Turinaung 6

\section{Latin:}

Lompo laloja anakku

Nanu balasaka te'ne

Nuteya lanre

Kukatuwo kasiyasi

Terjemahan:

Semoga nanti anakku besar

Kamu balas aku dengan kebahagiaan

Jangan engkau bosan

Kupelihara dengan keadaan miskin

\section{Lontara:}

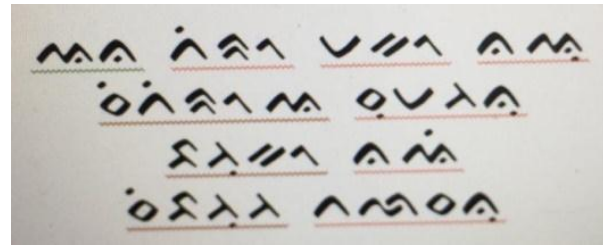

Gambar 9. Teks Lontara Royong Turinaung 7

\section{Latin:}

Ana' tinro mako naung

Sitinroang sumangaknu

Bangungko naik

sibangungang tallasaknu

\section{Terjemahan:}

Anak tidurlah kamu

Tidur dengan semangatmu

Bangunlah kamu

Bangun bersama hidupmu

8. Lontara:

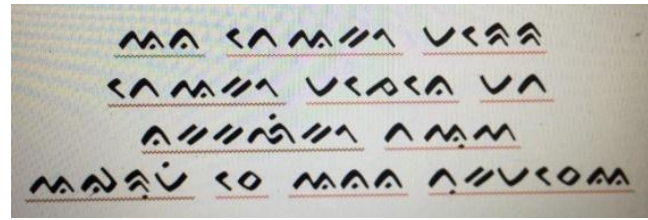

Gambar 10. Teks Lontara Royong Turinaung 8

\section{Latin:}

Anak teako marera 
Jurnal Inspirasi Pendidikan, VOL.9, NO.2, Edisi Agustus 2019

Royong Sebagai Bentuk Penanaman Nilai-Nilai Pendidikan

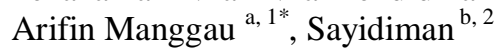
Hal: $123-133$

Teako makjekne mata

Nakakkaliko tauwa

Anggarrukmi seng anakna tukamaseya

Terjemahan:

Anak janganlah bersedih

Janganlah menangis

Orang-orang akan menertawaimu

Menangis lagi anak orang miskin

\section{Lontara:}

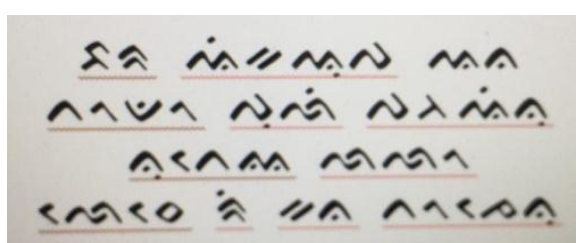

Gambar 11. Teks Lontara Royong Turinaung 9

\section{Latin:}

Barang ikaupa ana

Toddo puli pangngainnu

Nuteya lalo

Lesse ri kana tojengnu

Terjemahan:

Semoga kamu, nak

Tertancap perasaan kasih sayangmu

Semoga kamu tidak

Berpindah dari perkataan yang sesungguhnya

\section{Lontara:}

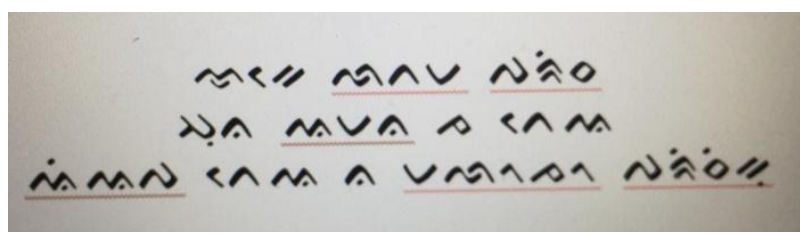

Gambar 12. Teks Lontara Royong Turinaung 10

\section{Latin:}

Nakke latama pakrisak

Punna ammakna ja tea

Iapa tea na ma'lonjo pakrisikku

Terjemahan:

Saya tidak akan sakit hati

Jika ibunya tidak mau

Saya akan sakit hati jika dia yang tidak mau

\section{Lontara:}

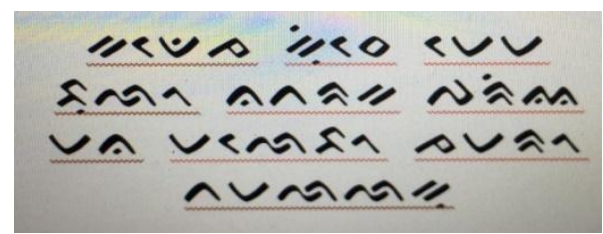

Gambar 13. Teks Lontara Royong Turinaung 11

Latin:

Ka'deja kuissseng memang 


\section{Bulo natangke pariya \\ Manna malebong \\ Jamarrok tama'lalangku \\ Terjemahan: \\ Jika kutahu dari dulu \\ Bambu bertangkai paria \\ Biarpun elok \\ Tidak akan saya mau}

\subsection{Syarat-Syarat Royong Pattinro Ana'}

Dari hasil wawancara kami dengan narasumber, orang dulu meyakini bahwa ketika menidurkan anak kecil ada beberapa hal yang tidak bisa kita lakukan, yakni sebagai berikut:

a) Tidak menidurkan anak pada waktu antara ashar dan magrib

b) Sebelum menidurkan seorang anak bayi berusia 40 hari di atas ayunan tersebut mereka menaikkan anak kucing terlebih dahulu ke atas ayunan. Mereka mempercayai hal tersebut untuk mengambil semangat dari kucing tersebut yang biasa disebut oleh masyarakat Makassar Nialle sumangakna

c) Tidak menidurkan anak menggunakan Royong ketika ada tetangga yang baru meninggal

d) Tidak menidurkan anak diluar rumah atau di depan pintu

Untuk royong pattinro ana' tidak memiliki syarat khusus di kalangan masyarakat Makassar pada umumnya. Untuk jenis sarung yang digunakan tidak ada yang istimewa artinya bisa menggunakan berbagai jenis sarung, selama sarung itu kuat dan tidak gampang robek. Untuk waktu di nyanyikannya royong pattinro ana' juga tidak terikat kecuali waktu antara ashar dan memasuki magrib. Mereka melarang untuk menidurkan anak bayi antara ashar dan memasuki magrib karena mereka mempercayai bahwa itu adalah pammali. Kepercayaan terhadap pammali yaitu kebiasaan yang dilarang dalam adat istiadat Bugis-Makassar. Ketika anak kecil sudah mulai mengantuk dan ingin tidur kita bisa meroyongkan mereka kecuali pada waktu yang disebutkan di atas. Ada baiknya dalam menidurkan anak dilakukan di dalam rumah karena masyarakat Makassar percaya diluar rumah banyak hal-hal yang tidak baik berkeliaran, dalam hal ini disebut sebagai sesuatu yang tidak baik seperti hal gaib yang dapat mengganggu anak kecil. Biasanya mereka takut jikalau menidurkan anak kecil diluar bisa membuat anak kecil tersebut sakit seperti disambar oleh makhluk halus ataupun sejenisnya.

Untuk menyanyikan royong pattinro ana' tidak diperlukan syair yang terikat, mereka bisa menyanyikan Royong pattinro ana' dengan syair apa saja selama kata-kata yang terdapat dalam syair itu mengandung hal-hal yang positif. Karena masyarakat Makassar mempercayai bahwa apa yang dilagukan dalam Royong pattinro ana' tersebut bisa jadi kenyataan suatu hari nanti. Dalam syair tersebut berisi harapan-harapan dan doa-doa yang dilantukan oleh pa'royong tersebut serta berisi nilai-nilai pendidikan. Ardina (2012)menjelaskan adanya sastra lisan yang terdapat pada siklus hidup pemeliharaan anak dalam masyarakat, dan adanya peran sastra lisan sebagai media penganjur nilai pendidikan dalam masyarakat. Dalam melantunkannya biasanya para wanita-wanita tua tersebut menangis karena menghayati syair yang mereka lantunkan.

\subsection{Nilai-Nilai yang Terkandung dalam Royong Pattinro Ana'}

Secara umum, Ada 4 macam fungsi Royong, yaitu:

1. Sebagai pengantar tidur;

2. Sebagai pengundang rezeki dan penolak bala atau penangkal malapetaka;

3. Sebagai pengesahan suatu adat atau tata cara kebiasaan kelompok masyarakat Makassar;

4. Sebagai media pendidikan budi pekerti atau pemahaman norma-norma positif kepada generasi penerus.

Dari ke-empat fungsi royong diatas dapat dijelaskan bahwa nilai-nilai yang terkandung dalam royong pattinro ana' sangat banyak. Adapun salah satu yang disebutkan di atas adalah sebagai media pendidikan budi pekerti atau pemahaman norma-norma positif kepada generasi penerus. Anak kecil yang diroyongkan diharapkan dapat mengetahui dan memahami norma-norma positif yang ada dan tidak melakukan hal-hal yang menyimpang dari yang diharapkan. Royong pattinro ana' juga berisi 
Jurnal Inspirasi Pendidikan, VOL.9, NO.2, Edisi Agustus 2019

Royong Sebagai Bentuk Penanaman Nilai-Nilai Pendidikan Arifin Manggau ${ }^{\text {a, }}{ }^{*}$, Sayidiman ${ }^{\text {b, } 2}$

Hal: 123-133

syair-syair yang penuh dengan pengharapan dan doa dari orang-orang tua kepada para anaknya untuk dapat tumbuh dan berkembang dengan baik. Karakter dapat dikembangkan melalui pendidikan seperti nyanyian adalah dapat meningkatkan "rasa" kepekaan, kreativitas dan rasa hormat (Sutawi, 2018).

Para orang tua juga terkadang melantukan syair royong dengan kesedihan yang berisi kata-kata sedih tentang berbagai hal yang terjadi dalam hidup. Royong pattinro ana' juga berfungsi sebagai sarana untuk memberikan semangat dalam menjalani hidup, sabar dan ikhlas, tidak pantang menyerah dan senantiasa bersyukur kepada Tuhan Yang Maha Kuasa. Dalam syair royong juga biasanya terdapat makna yang berkonotasi dengan maksud menyinggung sesuatu yang negatif. Sesuatu yang negatif ini dijadikan pembelajaran untuk mengambil hikmah atas segala sesuatu yang buruk yang terjadi dalam hidup yang menimpa seseorang.

Contoh syair Royong yang bermakna konotasi sebagai berikut.

\section{Lontara:}

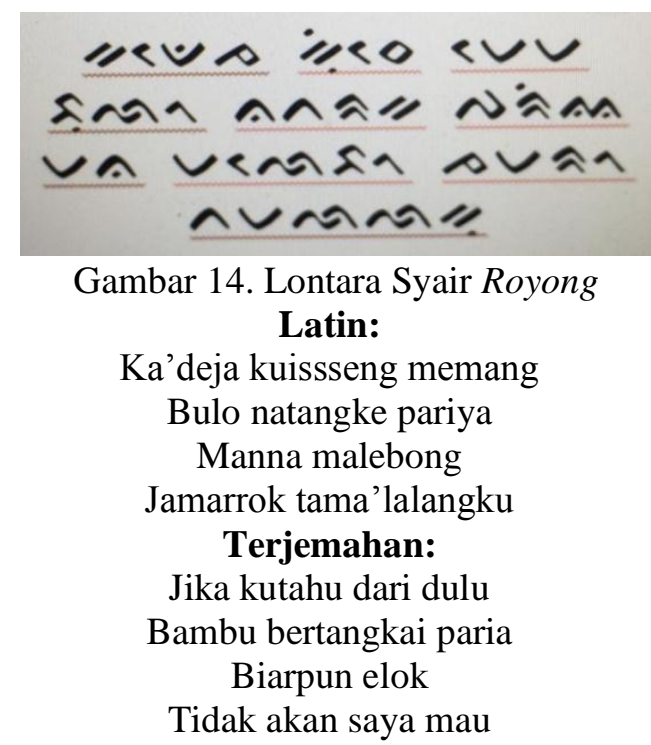

Maksud dari syair di atas adalah seseorang yang menyesal mengenal seseorang karena melihat rupanya saja, luarannya bagus tetapi, ternyata sifat yang dimilikinya tidak secantik rupanya. Selain dipahami sebagai bentuk kesenian atau musik vokal, royong juga dikenal memiliki nilai-nilai sosial budaya pada masyarakat pendukungnya. Royong dalam tradisi masyarakat Makassar bersifat sakral. Pada hakikatnya Royong merupakan doa khas tradisional yang disajikan dalam bentuk nyanyian (musik vokal) dan mengandung nilai-nilai simbolis-religius. Sebagai doa, royong bagi masyarakat Makassar merupakan hal yang mistis. royong merupakan suatu cara untuk melakukan penghayatan spiritual yang intens dan penuh ketakjuban terhadap kekuatan gaib, kekuatan supranatural. Masyarakat meyakini bahwa melalui musik vokal royong kekuatan-kekuatan gaib yang menguasai alam semesta dapat diatasi. Secara konsepsional, royong merupakan abstraksi dari cara pandang masyarakat Makassar terhadap alam semesta. Pandangan terhadap makrokosmos dan mikrokosmos yang perlu dijaga keserasian dan keseimbangannya. Masyarakat Makassar memandang alam ini dalam dua dimensi, yaitu alam yang dapat dikuasai (alam natural) dan alam yang tidak dapat dikuasai (alam supranatural). Oleh karena itu perlu dijaga hubungan yang harmonis, antara alam natural, di mana manusia sebagai tuan, dengan alam supranatural yang menempatkan manusia sebagai hamba. Dari pandangan tersebut, masyarakat Makassar membuat suatu media berkomunikasi dengan kekuatan supranatural. Media berkomunikasi tersebut disebut royong.

\section{Fungsi Royong}

Royong merupakan tradisi pra Islam dimana tradisi ini telah hadir jauh sebelum agama Islam menjejakkan kakinya di daerah Makassar (Kamal, 2015). Meskipun demikian, masyarakat Makassar yang menganut agama Islam tetap menjalankan royong. Sesuai dengan fungsinya sebagai sebuah musik vokal yang sifatnya ritual, tradisi royong hanya dipentaskan pada upacara-upacara adat 
kerajaan dan dalam siklus kehidupan manusia (life cycle), khususnya di kalangan bangsawan, mulai dari kehamilan, kelahiran, keremajaan, dan perkawinan. Setiap bayi yang lahir dalam masyarakat Makassar dan berasal dari golongan bangsawan harus menjalani upacara ritual selamatan yang di dalamnya terdapat Royong (prosesi ini disebut ni royongi). Royong dianggap memiliki peran dan fungsi yang sangat penting, sehingga selalu dihadirkan dan menjadi satu kesatuan dengan upacara ritual yang dilaksanakan. Royong dipercaya mampu menghubungkan alam manusia dan alam gaib. Masyarakat Makassar meyakini bahwa royong dapat menolak bala dan menjauhkan dari roh-roh jahat. Secara perlahan, perubahan yang terjadi pada royong, berakibat pada nilai kesakralan Royong semakin berkurang. Dahulu royong merupakan nyanyian ritual yang penuh dengan nilai sakral. Sebuah nyanyian disenandungkan oleh pa'royong (sang vokalis Royong) yang berfungsi sebagai media komunikasi spiritual dengan Yang Maha Kuasa. Komunikasi gaib untuk menolak bala dan menjauhkan dari roh jahat. Royong pada saat itu berfungsi untuk menjaga keseimbangan makrokosmos dan mikrokosmos. Namun sekarang Royong hanya sekedar ritual nyanyian sebagai pelengkap atau hiasan dalam setiap upacara adat. Ia menjadi pemeriah dalam setiap pementasannya. Tidak lagi menampakkan kesakralannya. Beberapa aturan pementasan sudah tidak dilaksanakan, seperti aturan jajakang, ritual apparuru, termasuk kelengkapan peralatan dan kostum tidak lagi diperhatikan. Royong hanya hadir sebagai pemeriah dan sarana hiburan yang tampil dalam panggung pagelaran. Hanya sebagai pelengkap dan bukan lagi menjadi bagian terpenting karena nilai-nilai pendidikan yang ingin ditanamkan dari suatu upacara yang digelar(Lestari, 2012).

\section{Perkembangan Royong Dewasa Ini}

Sastra lisan Royong dewasa ini mengalami masa menghampiri kepunahan. Selain ia kehilangan tradisinya lantaran para bangsawan kerajaan Gowa tidak lagi melaksanakan upacara daur hidup (life cycle rites) secara tradisional akan tetapi melaksanakannya dengan sederhana, dan mengikuti ajaran syariat Islam yang tidak lagi membutuhkan kehadiran royong sebagai media permohonan do'a sehingga secara perlahan-lahan sastra royong sangat jarang dituturkan lagi. Juga pendukung atau pelaku royong sudah lanjut usia. Rata-rata usia pa'royong sekarang ini di atas 70 tahun.Yang unik dari tradisi lisan ini karena royong hanya bisa diwariskan kepada kaum perempuan dalam lingkungan keluarga pa'royong itu sendiri. Seseorang bisa menjadi pa'royong bila mempunyai garis keturunan pa'Royong. Itupun bukan karena kemauan sendiri akan tetapi "dipilih oleh suatu kekuatan gaib" yang ditandai dengan kesurupan atau sakit beberapa hari. Penunjukannya sebagai pa'royong berlangsung secara gaib yang merupakan kehendak dari arwah leluhur bersemayam di dalam kalompoang (boe-boe). Seorang yang "terpilih" akan mengalami kejadian aneh. Kejadian ini baru berhenti bila yang terpilih telah melakukan suatu ritual, sebagai tanda setuju untuk menjadi pa'royong. Peralatan royong yang telah diwariskan juga harus dijaga dengan baik, pada waktu-waktu tertentu perlu diberikan jajakang. Dalam penyajiannya, vokalis royong tidak menyebutkan secara jelas isi syairnya, tetapi hanya menyebutkan bunyi vocal misalnya /eee/ atau /ooo/ dan berupa kata yang merupakan sambungan-sambungan kalimat atau syair yang akan diungkapkan. Sebagai contoh dalam salah satu bait syair Royong yang biasa dinyanyikan dalam upacara aqiqah (passili)..."

\section{Bolaeng Intan Jamarro Panggaukanna Situju Batang Kalenna, Batenna Nagoya"...akan dilakukan oleh pa'Royong seperti: ....Booooo-laaaaaa-eeeeeng-iiiintaaan-jaaaaaa-maaaaaa- \\ rrooooоoораaаaaaaang-gaaaaaa-иииии-kaaaan-naaaa-siii-tиии-juии-baaaa-taaaang-kaaaaleee- naaa-baaaa-teeee-nnaaaa-naaaaaa-gooo-yaaaa ...}

Penyebutan bunyi vocal yang panjang merupakan ciri dari pelantunan royong. Jadi, terkadang pendengar tidak jelas menangkap kalimat lagunya. Terlebih lagi kebiasan pa'Royong pada saat melantunkan syair Royong selalu menutup mulutnya dengan selendangnya. Biasanya royong dilantunkan semalam suntuk.

\section{Simpulan}

Royong adalah nyanyian pengantar tidur untuk bayi atau anak kecil yang dilantunkan tanpa diiringi musik, sambil bayi diayun-ayunkan perlahan sampai tidur terlelap. Di mana, royong ini 
Jurnal Inspirasi Pendidikan, VOL.9, NO.2, Edisi Agustus 2019

Royong Sebagai Bentuk Penanaman Nilai-Nilai Pendidikan Arifin Manggau ${ }^{\text {a, }}{ }^{*}$, Sayidiman ${ }^{\text {b, } 2}$

Hal: 123-133

memiliki beberapa fungsi yaitu sebagai pengantar tidur, penanaman nilai pendidikan dan mendatangkan rezeki. Royoan digunakan dalam beberapa adat atau kebiasaan masyarakat Makassar seperti : perkawinan, aqiqah, penolak bala, serta sebagai media pola asuh pada anak (penanaman budi pekerti etika yang baik). Dewasa ini, royong sudah menghampiri kepunahan karena para bangsawan kerajaan Gowa tidak lagi melaksanakan upacara daur hidup (life cycle rites) secara tradisional akan tetapi melaksanakannya dengan sederhana, dan mengikuti ajaran syariat Islam yang tidak lagi membutuhkan kehadiran Royong sebagai media permohonan do'a sehingga secara perlahan-lahan sastra Royong sangat jarang dituturkan lagi. Juga pendukung atau pelaku Royong sudah lanjut usia. Rata-rata usia Pa'Royong sekarang ini di atas 70 tahun yang mungkin saat ini sudah meninggal. Menidurkan bayi dengan dinyanyikan lagu pengantar tidur (Royong), merupakan pola asuh seorang $\mathrm{ibu/} \mathrm{nenek} \mathrm{kepada} \mathrm{anak/} \mathrm{cucunya} \mathrm{karena} \mathrm{isi/} \mathrm{lirik} \mathrm{lagunya} \mathrm{mengandung} \mathrm{ajaran} \mathrm{moral,} \mathrm{nasehat} \mathrm{atau}$ doa-doa untuk anaknya yang dijadikan salah satu cara membuat anak selalu ingat akan petuah/ ajaran yang diucapkan ibu/ neneknya

\section{Referensi}

Al-Afandi. (2015). Fungsi dan Nilai Nyanyian Buaian dalam Sastra Lisan Kaili. BAHASANTODEA, 4(3), 81-92. $\quad$ Retrieved from http://jurnal.untad.ac.id/jurnal/index.php/Bahasantodea/article/view/6333

Ardina, M. D. (2012). Implementasi Pembelajaran Musik Untuk Mengembangkan Mental Dan Psikomotorik Anak Penderita Down Syndrom. Harmonia: Journal of Arts Research and Education, 12(2), 125-131. Retrieved from https://journal.unnes.ac.id/nju/index.php/harmonia/article/view/2520

Frankel, J. P., \& E., W. N. (2008). How To Design an Evaluate Research in Education. New York: McGraw-Hill Companies, inc.

Kamal, Z. (2015). Nyanyian Anak Balam: Terapi Mistik Perdukunan ke Seni Pertunjukan Rabab Pasisie di Pesisir Selatan Sumatera Barat. Humanus: Jurnal Ilmiah Ilmu-Ilmu Humaniora, 14(2), 165-173. Retrieved from http://ejournal.unp.ac.id/index.php/humanus/article/view/5683

Lestari, R. (2012). Nyanyian Sebagai Metode Pendidikan Karakter Pada Anak. In Prosiding Seminar Nasional Psikologi Islami. Surakarta: Fakultas Psikologi Universitas Muhammadiyah Surakarta.

Moleong, L. J. (2007). Metodologi Penelitian Kualitatif. Bandung: Remaja Rosdakarya.

Salim, A. (2011). Ekspresi Kebijaksanaan Suku bugis Wajo Memelihara Anak (Analisis Sastra Lisan). Jurnal Al-Qalam, 17(1), 125-132. Retrieved from http://jurnalalqalam.or.id/index.php/Alqalam/article/viewFile/105/91

Sugiyono. (2013). Metode penelitian Kuantitatif Kualitatif dan R\&D. Bandung.: Alfabeta.

Sumaryanto, F. T. (2007). Pendekatan Kuantitatif dan Kualitatif; Dalam Penelitian Pendidikan Seni. Semarang: UNNES PRESS.

Sutawi, T. K. (2018). Three Characters Moulded in Music Education. Harmonia: Journal of Arts Research and Education, 18(2), 200207. Retrieved from https://doi.org/10.15294/harmonia.v18i2 